\title{
Twenty Traditional Algerian Plants Used in Diabetes Therapy as Strong Inhibitors of $\alpha$-Amylase Activity
}

\author{
Ihcen Khacheba, Amar Djeridane, and Mohamed Yousfi \\ Laboratoire des Sciences Fondamentale, Université Amar Telidji, Laghouat, Algeria \\ Correspondence should be addressed to Mohamed Yousfi; yousfim8@gmail.com
}

Received 1 May 2014; Revised 7 July 2014; Accepted 8 July 2014; Published 5 August 2014

Academic Editor: Jianjun Li

Copyright ( 2014 Ihcen Khacheba et al. This is an open access article distributed under the Creative Commons Attribution License, which permits unrestricted use, distribution, and reproduction in any medium, provided the original work is properly cited.

\begin{abstract}
In the present work, we have studied the inhibitory effects of aqueous and alcoholic extracts of six Algerian medicinal plants known by their therapeutic virtues against diabetes. The total phenolic compounds content, assayed using Folin-Ciocalteu's reagent, of the samples ranged from $0.183 \mathrm{mg} / \mathrm{g}$ to $43.088 \mathrm{mg} / \mathrm{g}$ and from $1.197 \mathrm{mg} / \mathrm{g}$ to $7.445 \mathrm{mg} / \mathrm{g}$, expressed as gallic acid equivalent (GAE), for the, respectively, whereas the total flavonoids concentrations, detected using $2 \%$ of the aluminium chloride, ranged from $0.41 \mathrm{mg} / \mathrm{g}$ to $11.613 \mathrm{mg} / \mathrm{g}$ and from $0.0097 \mathrm{mg} / \mathrm{g}$ to $1.591 \mathrm{mg} / \mathrm{g}$, expressed as rutin equivalents (RE), for the aqueous and methanolic extracts, respectively. The major plants were found to inhibit enzymatic activities of Aspergillus oryzae-amylase in a concentration dependent manner. The values of the inhibition constants $\left(K_{i}\right)$ have been determined according to the Dixon and Lineweaver-Burk methods. The results showed that the $K_{i}$ values were less than $55 \mathrm{ppm}$ for the all extracts. A strong inhibition was found in the phenolic extract of Salvia officinalis with a $K_{i}$ of $8 \mathrm{ppm}$.
\end{abstract}

\section{Introduction}

Diabetes mellitus (DM) is a chronic metabolic disorder caused by an absolute or relative lack of resistance to insulin. It is characterized by hyperglycemia and accompanied by various chronic vascular complications [1-3]. About 171 million people worldwide have diabetes, which is likely to be more than double by 2030 and around 3.2 million deaths every year are attributable to complication of diabetes, six deaths every minute $[4,5]$.

One therapeutic approach to decrease the hyperglycemia is to retard and reduce the digestion and absorption of ingested carbohydrate hydrolyzing enzymes (such as $\alpha$ amylase and/or $\alpha$-glucosidase) in the digestive organs [610]. The inhibition of enzymes involved in the digestion of carbohydrates can significantly decrease the postprandial increase of blood glucose after a mixed carbohydrate diet by delaying the process of carbohydrate hydrolysis and absorption [6,11-13]. Therefore, safer natural amylase and glucosidase inhibitors have been reported from plant sources [14-16].

Arising from their biodiversity and their wealth of active ingredients, plants have been used from antiquity as sources of medicament against various diseases. These properties are usually attributed to secondary metabolites that are the subject of a lot of research in this field. This is particularly the case of polyphenol plants that are widely renowned in therapeutics as anti-inflammatories, enzyme inhibitors, and antioxidants, particularly flavonoids [6, 17-19].

Plant hypoglycemic properties have been used in folk medicine from very ancient time. Medicinal plants used to treat hyperglycemic are of considerable interest to ethnobotanical community as they are recognized to contain valuable medicinal properties in different parts of the plant $[7,11,20]$ and, because of their effectiveness, fewer side effects and relatively low cost. To this end, research has begun to embrace traditional medicines from various cultures, as scientists search for clues to discover new therapeutic drugs $[7,21]$.

In the town of Laghouat in the steppe region of Algeria, the list of plants that fit neatly within this framework is exhaustive; they are used as teas, extracts, or complex preparations, without knowing the mechanism of treatment.

In this study, we reported the screening results for amylase inhibitory activity of 21 herbal extracts, to confirm their antidiabetic activity by the inhibition of $\alpha$-amylase. 
TABLE 1: The name and the aerial part of the 21 plants.

\begin{tabular}{ll}
\hline Name & Aerial part used \\
\hline Ajuga iva & All the aerial parts \\
Aloe socotrina & The resins \\
Anthemis arvensis & The flowers \\
Berberis vulgaris & The bark \\
Cistus & The leaves and stems \\
Equisetum arvense & Grains and leaves \\
Erythraea centaurium & All the aerial parts \\
Haloxylon scoparium & The flowers \\
Helianthemum lippii & All the aerial parts \\
Marrubium vulgare & All the aerial parts \\
Matricaria pubescens & All the aerial parts \\
Ononis angustissima & The leaves \\
Oudneya africana & The pods and the leaves \\
Pituranthos chloranthus & The grains \\
Rhamnus alaternus & The leaves \\
Rhanterium adpressum & The flowers \\
Salvia officinalis & All the aerial parts \\
Teucrium polium & All the aerial parts \\
Thapsia garganica & The flowers \\
Trigonella foenum & The grains \\
Zygophyllum album & All the aerial parts \\
\hline
\end{tabular}

Therefore we have proceeded to the extraction of the polar bioactive compounds of the 21 different medicinal plants with two polar solvents, and we have tested the effect of these extracts on the enzymatic activity to confirm their inhibitory activities. This is the first work in the validation of some local plants used frequently in traditional Algerian medicine.

\section{Materials and Methods}

2.1. Plant Material. 21 plants have been evaluated in this study. The names and the parts used in each plant are summarized in Table 1 . The plants selected for the study of the inhibitory effect on $\alpha$-amylase activity are Equisetum arvense (Equisetaceae), Matricaria pubescens (Asteraceae), Oudneya africana (Brassicaceae), Salvia officinalis (Lamiaceae), Thapsia garganica (Ombellifereae), and Cistus whose type has not been determined.

Nine of these medicinal plants were purchased from different herbalists of Laghouat City because they are known by their therapeutic effect against diabetes mellitus, the others plants were collected from different locations around the town of Laghouat in the steppe region of Algeria. The various data (local name, medicinal uses, used parts of plant, method of preparation, and administration) were collected from local inhabitants and herbalists having knowledge of the curative properties of these plants.

2.2. Reagents. All chemicals were purchased from Sigma (USA), Aldrich (Milwaukee, USA), Fluka Chemie (Buchs, Switzerland), and Merck (Germany).
2.3. Extraction. Assuming that the active ingredients are polar compounds, the extraction of these was made initially with distilled water. The air-dried aerial parts of each plant were finely powdered. One gram of each powder was heated in $20 \mathrm{~mL}$ of distilled water at $75^{\circ} \mathrm{C}$ for 20 minutes. The extract was filtered and evaporated to dryness using a rotary evaporator. The dried residue was dissolved in $5 \mathrm{~mL}$ of distilled water and kept at $4^{\circ} \mathrm{C}$.

Depending on the results of the inhibition test on the enzyme activity, we have selected six plants from the plants investigated which are "Cistus," "Oudneya africana," "Equisetum arvense," "Matricaria pubescens," "Salvia officinalis," and "Thapsia garganica" which showed inhibition rate above $70 \%$. The six selected plants are subjected to a series of extractions with distilled water and methanol. $1 \mathrm{~g}$ of the plant powder was heated in $20 \mathrm{~mL}$ of distilled water for $20 \mathrm{~min}$ at $75^{\circ} \mathrm{C}$.

After filtration, the residues of the plant were then macerated for $72 \mathrm{~h}$ with $10 \mathrm{~mL}$ of absolute methanol. The filtrates obtained from both extraction steps are evaporated to dryness and the precipitate was dissolved in $5 \mathrm{~mL}$ of distilled water and $5 \mathrm{~mL}$ of absolute methanol for aqueous extracts and methanoïque extracts, respectively. The plant extracts were kept at $4^{\circ} \mathrm{C}$.

2.4. Determination of Total Phenolics Compound. The amount of total phenolics in the samples was determined with the Folin-Ciocalteu reagent using the method of Singleton and Ross (1965) [22]. The procedure is as follows: $100 \mu \mathrm{L}$ of each sample was added to $500 \mu \mathrm{L}$ of the aqueous solution of Folin-Ciocalteu reagent at $10 \%$. After 2 min of incubation at room temperature, $2 \mathrm{~mL}$ of $2 \%(\mathrm{w} / \mathrm{v})$ sodium carbonate in water was added. Blanks were prepared by replacing the reagent by water to correct for interfering compound. After $30 \mathrm{~min}$ of incubation in the dark at room temperature, the absorbance of all samples was measured at $760 \mathrm{~nm}$ using the Shimadzu 1601 visible spectrophotometer. The gallic acid was used as a standard and all the assays were carried out at least in triplicate.

2.5. Quantification of Flavonoids Content. The flavonoids content in the extracts was determined spectrophotometrically according to the method of Laimaison and Carnat (1991) [23], using a method based on the formation of the complex flavonoids-aluminium, having an absorption maximum at $409 \mathrm{~nm}$. Rutin was used for the calibration curve. $1 \mathrm{~mL}$ of diluted sample was mixed with $1 \mathrm{~mL}$ of $2 \%$ aluminum chloride methanolic solution. After incubation at room temperature for $20 \mathrm{~min}$, the absorbance of the reaction mixture was measured at $409 \mathrm{~nm}$ with a Shimadzu 1601 visible spectrophotometer and the flavonoids content is expressed in mg per g rutin equivalent (RE) of dry weight material.

2.6. Assay for Fungal $\alpha$-Amylase Inhibitory Activity. In the first time, we have tested the effect of the 23 aqueous extracts at the same concentration on the $\alpha$-amylase activity.

The fungal $\alpha$-amylase inhibitory activity was determined according to a literature method [24], on its substrate starch using neocuproine as a reagent. 
The method is based on the reducing power of the maltose product that reacts with a basic solution of glycine-copper (A solution) with blue color, developing a yellow orange color in the presence of neocuproine (B solution).

In brief, $200 \mu \mathrm{L}$ of sodium phosphate buffer containing $6 \mathrm{mM} \mathrm{NaCl}(\mathrm{pH} 6,9)$ was mixed with $100 \mu \mathrm{L}$ of soluble starch $(0.05 \%)$ as a substrate and $100 \mu \mathrm{L}$ of suitable aliquots of our aqueous extracts, whereas $100 \mu \mathrm{L}$ of the buffer was used in the place of the plant extract for the blank sample. After thoroughly mixing, both sample and blank test tubes were preincubated at $37^{\circ} \mathrm{C}$ for $10 \mathrm{~min}$; then the reaction is started by the addition of $100 \mu \mathrm{L}$ of $\alpha$-amylase from Aspergillus oryzae (13 units; one unit of enzyme activity is defined as the amount of enzyme required to release one micromole of maltose from starch per minute under assay conditions). After incubation at $37^{\circ} \mathrm{C}$ for $5 \mathrm{~min}$ the reaction was stopped by adding $1 \mathrm{~mL}$ of A solution and $1 \mathrm{~mL}$ of $\mathrm{B}$ solution. The reaction mixture was incubated at $100^{\circ} \mathrm{C}$ for $10 \mathrm{~min}$; after that the tubes have been cooled with tap water.

Enzyme activity was quantified by measuring optical density proportional to the quantity of the maltose equivalents released from starch at $450 \mathrm{~nm}$ and the inhibitory activity was calculated using the following formula:

$$
\operatorname{Inhibitory} \operatorname{activity}(\%)=\left[\frac{\left(A_{0}-A_{s}\right)}{A_{0}}\right] \times 100 \text {, }
$$

where $A_{0}$ is absorbance of control without inhibitor, and $A_{s}$ is absorbance of test sample with inhibitor.

\section{Results and Discussion}

3.1. Total Phenolic Content. The polar extracts of twenty plants known for their therapeutic properties against diabetes in traditional Arab medicine were tested for their inhibitory activity towards purified fungal $\alpha$-amylase. A number of spectrophotometric methods for quantification of phenolic compound in plant materials were developed. These tests were based on different principles and were used to determine the various structural groups present in phenolic compounds [25]. The phenolic content of each plant extract was estimated by the Folin-Ciocalteu procedure, and the amount of polyphenols in the plants was calculated from the calibration curve of gallic acid previously realized and expressed in milligrams of gallic acid equivalents per gram of dry matter, while the quantification of flavonoids in our extracts was determined by complexation with trichloride aluminum from the calibration curve of rutin and expressed in milligrams of rutin equivalent per gram of dry matter (Table 2).

So far, as plant phenolics constitute one of the major groups of compounds acting as enzyme inhibitor, it was reasonable to determine their total amount in the selected plant extracts. Flavonoids as one of the most diverse and widespread groups of natural compounds are probably the most important natural phenolics [17, 26, 27]. These compounds possess a broad spectrum of chemical and biological activities including radical scavenging properties and enzyme
TABLE 2: Total amount of plant phenolics compound and flavonoids.

\begin{tabular}{|c|c|c|}
\hline Name of plant & $\begin{array}{l}\text { Total phenolics } \\
\text { content } \\
(\mathrm{mg} \mathrm{GAE} / \mathrm{gdw})^{\mathrm{a}}\end{array}$ & $\begin{array}{c}\text { Flavonoids } \\
\text { content } \\
(\mathrm{mg} \mathrm{RE} / \mathrm{g} \mathrm{dw})^{\mathrm{b}}\end{array}$ \\
\hline Ajuga iva & $1.80 \pm 0.03$ & $0.66 \pm 0.02$ \\
\hline Aloe socotrina & $8.91 \pm 0.06$ & $8.39 \pm 0.07$ \\
\hline Anthemis arvensis & $3.94 \pm 0.05$ & $0.95 \pm 0.04$ \\
\hline Berberis Vulgaris & $6.74 \pm 0.09$ & $0.53 \pm 0.1$ \\
\hline Cistus & $43.08 \pm 0.02$ & $2.07 \pm 0.01$ \\
\hline \multicolumn{3}{|l|}{ Equisetum arvense } \\
\hline (i) The grains & $2.48 \pm 0.07$ & $0.06 \pm 0.08$ \\
\hline (ii) The leaves & $1.92 \pm 0.31$ & $0.51 \pm 0.3$ \\
\hline Erythraea centaurium & $7.32 \pm 0.14$ & $6.49 \pm 0.15$ \\
\hline Haloxylon scoparium & $26.71 \pm 0.15$ & $1.73 \pm 0.12$ \\
\hline Helianthemum lippii & $1.39 \pm 0.01$ & $1.35 \pm 0.02$ \\
\hline Marrubium vulgare & $1.36 \pm 0.07$ & $0.21 \pm 0.06$ \\
\hline Matricaria pubescens & $1.71 \pm 0.03$ & $0.43 \pm 0.04$ \\
\hline Ononis angustissima & $1.91 \pm 0.52$ & $1.16 \pm 0.51$ \\
\hline \multicolumn{3}{|l|}{ Oudneya africana } \\
\hline (i) The pods & $9.17 \pm 0.04$ & $3.61 \pm 0.03$ \\
\hline (ii) The leaves & $15.86 \pm 0.02$ & $6.54 \pm 0.03$ \\
\hline Pituranthos chloranthus & $3.62 \pm 0.46$ & $0.91 \pm 0.36$ \\
\hline Rhamnus alaternus & $3.01 \pm 0.02$ & $2.11 \pm 0.03$ \\
\hline Rhanterium adpressum & $2.88 \pm 0.33$ & $1.11 \pm 0.30$ \\
\hline Salvia officinalis & $16.12 \pm 0.30$ & $11.61 \pm 0.15$ \\
\hline Teucrium polium & $5.61 \pm 0.01$ & $3.00 \pm 0.05$ \\
\hline Thapsia garganica & $8.10 \pm 0.04$ & $2.83 \pm 0.03$ \\
\hline Trigonella foenum & $0.18 \pm 0.08$ & $0.04 \pm 0.07$ \\
\hline Zygophyllum album & $2.16 \pm 0.005$ & $1.97 \pm 0.01$ \\
\hline
\end{tabular}

${ }^{a}$ Milligrams of gallic acid equivalent per gram of dry weight of plant.

${ }^{b}$ Milligrams of rutin equivalent per gram of dry weight of plant.

inhibition [2, 28-30]. Therefore, the content of this group of phenolics was determined in the extracts.

The content of phenolic compounds ( $\mathrm{mg} / \mathrm{g}$ ) in the 23 aqueous extracts of the 20 plants tested varied between 0.18 and $43.088 \mathrm{mg} / \mathrm{g}$. The highest amounts were found in the extract of "Trigonella foenum" while the lowest amounts were found in the extract of "Cistus." The plant Helianthemum kahiricum showed the highest values in total phenols in the two dichloromethane and ethyl acetate fractions against the plant Salsola baryosma which showed the lowest value.

The amount of total phenolic compounds in all the tested plants is less than that in other studies on other plant species in the region of Laghouat [31], but near to other studies of Djeridane et al. [32]. This lowness among our plants may be related to a poverty of our plant in polyphenols and probably to favorable biotic conditions our plants grew in which did not stimulate the biosynthesis of these molecules. The content of flavonoids ( $\mathrm{mg} / \mathrm{g})$, in rutin equivalents, varied from 0.041 to 11.613 . The highest amounts of flavonoids were found in the aqueous extract of Salvia officinalis. All the aqueous extracts showed the presence of flavonoid. The plant 
TABLE 3: Total amount of phenolics compound and flavonoids of the six methanolic extracts.

\begin{tabular}{lcc}
\hline Nom de la plante & $\begin{array}{c}\text { Teneur en } \\
\text { phénols totaux: } \\
\mathrm{mg} / \mathrm{g} \text { MS }\end{array}$ & $\begin{array}{c}\text { Teneur en } \\
\text { flavonoïdes: } \\
\mathrm{mg} / \mathrm{g} \mathrm{MS}\end{array}$ \\
\hline Cistus & $5.71 \pm 0.01$ & $2.03 \pm 0.001$ \\
Equisetum arvense (the grains) & $2.45 \pm 0.005$ & $0 \pm 0.00$ \\
Matricaria pubescens & $3.16 \pm 0.05$ & $1.04 \pm 0.006$ \\
Oudneya africana (the pods) & $7.06 \pm 0.1$ & $0.27 \pm 0.003$ \\
Salvia officinalis & $11.42 \pm 0.004$ & $0.02 \pm 0.10$ \\
Thapsia garganica & $1.87 \pm 0.2$ & $0 \pm 0.00$ \\
\hline
\end{tabular}

Salvia officinalis showed the presence of the highest amounts of both phenols and flavonoids which can be explained by the fact that this plant was grown in bad weather conditions causing the synthesis of large quantity in phenolic compound.

If we compare the values of these flavonoids contents to those of phenolic compounds, we see that they are all smaller than the latter, indicating that the extracts contain other phenolic compounds having chemical structures other than flavonoids (phenolic acid, tannins, stilbenes, etc.). Some plants have proven rich in flavonoids such as Aloe socotrina, Erythraea centaurium, and Helianthemum lippii.

Following the inhibition test of the twenty plants investigated in this work, we have selected six plants that have a percentage higher than $70 \%$ for the further study of more inhibitory activity by calculating their $K_{i}$. For these six plants we have repeated a similar extraction to that of the twenty plants followed by maceration in absolute methanol.

The quantification of total phenols and flavonoids in the six methanoïque extracts was performed by the same procedures described above. The results are summarized in Table 3.

The content of phenolic compounds $(\mathrm{mg} / \mathrm{g})$ in the six methanolic extracts varied between 2.45 and $11.42 \mathrm{mg} / \mathrm{g}$. The plant Salvia offisinalis showed the highest values in total phenols against the plant Equisetum arvense which showed the lowest value.

If we compare the content of phenolic compounds in both aqueous and methanolic extracts of the six plants studied, we note that the aqueous extracts contain a higher amount of total phenols compared to the methanolic extracts. A simple explication can be considered by the fact that the methanol extraction has been preceded by an aqueous extraction, the methanol was extracted the compounds which are not extract in distilled water excepted the methanol extract of "Matricaria pubescens" which presented a total phenolic content higher than the aqueous extract which can be explained by the fact that the plant "Matricaria pubescens" contains other phenolics compounds non-extractable by water and which are passed into the methanol. Also, the distilled water has the ability to extract other polar compounds as polyphenols, such as alkaloids, proteins, sugars, and other compounds which are assayed by the Folin Cioncalteu procedure, resulting in increased levels of phenolics. Through the results listed in Table 3, we see that the plants studied contain a poor material in flavonoids mainly the extracts of the two plants Equisetum arvense (the grains) and Thapsia garganica which can be explained by the fact that this plant contains other classes of phenolics compound except the flavonoids.

3.2. Inhibition of Fungal $\alpha$-Amylase. In order to confirm the antidiabetic effect of these 20 plants by the inhibition of the fungal $\alpha$-amylase used in this work, we studied in vitro the effects of our phenolic extracts on the activities of the enzyme, at varying concentrations of extracts and substrates, to identify plants with inhibitory abilities on the enzyme.

The enzymatic activities of $\alpha$-amylase were titrated using starch as a substrate which releases maltose with a spectrophotometer detection after reaction with complexing agents.

Based on the calibration curve of maltose, we have determined the concentrations of maltose liberated in the reaction for different concentrations of starch. The values of concentrations allowed us to plot that the enzyme shows a kinetic similar to the kinetic of Michaelis.

To identify plants with inhibitory capacities we subjected our aqueous extracts to inhibition assay at the same concentration of extracts. These tests showed that all aqueous extracts have a significant inhibition of $\alpha$-amylase enzyme with the exception of two plants "Zygophyllum album" and "Trigonella foenum" (Table 4).

According to the results, we note that different levels of inhibition ranged between 8.29 and 100\%. The most important percentages of inhibition are noted for the extracts of "Cistus," the pods of "Oudneya Africana," and the grains of "Equisetum arvense."

The inhibition rates in almost all of the tested plants are higher than that in other studies on other plant species in the region of Laghouat of the studies of khacheba et al. [33]. This high among registered for our plants may be related to a type of extraction (infusion) and the highly polar nature of the solvent used which extracts a large number of inhibitory molecules which explains the use of these herbal plants by infusion in traditional medicine.

The herbalists confirm that, by the use of "Zygophyllum album" in traditional medicine against diabetes, we can explain the noninhibition of its aqueous extract by another level to reduce high blood sugar levels which is due to the inhibition of $\alpha$-glucosidase or by promoting the secretion of insulin. Another explanation proposed is that the active ingredients responsible for the inhibition of the enzyme are not extractable by distilled water.

Following the inhibition rates of the 23 aqueous extracts of the investigated plants, we have chosen six plants that have a percentage higher than $70 \%$ such as Cistus, Equisetum arvense (the grain), Matricaria pubescens, Oudneya africana (the pods), Salvia officinalis, and Thapsia garganica, for a new and a same extraction with distilled water followed by an extraction with methanol to investigate the type of enzyme inhibition and to determine the inhibition constants $\left(K_{i}\right)$ for each extract. The $\alpha$-amylase activities were assayed in the presence of different concentrations of the substrate $(0.4-1.11 \mathrm{~g} / \mathrm{L})$ and different concentrations of aqueous and 
TABLE 4: The inhibition rates of the 23 aqueous extracts.

\begin{tabular}{lc}
\hline Name of plant & Inhibition rates (\%) \\
\hline Ajuga iva & $70.31 \pm 0.001$ \\
Aloe socotrina & $30.19 \pm 0.005$ \\
Anthemis arvensis & $61.95 \pm 0.002$ \\
Berberis Vulgaris & $48.17 \pm 0.1$ \\
Cistus & $\mathbf{1 0 0} \pm 0.0005$ \\
Equisetum arvense & \\
(i) The grains & $\mathbf{1 0 0} \pm 0.0008$ \\
(ii) The leaves & $32.48 \pm 0.2$ \\
Erythraea centaurium & $25.69 \pm 0.3$ \\
Haloxylon scoparium & $53.61 \pm 0.01$ \\
Helianthemum lippii & $43.18 \pm 0.02$ \\
Marrubium vulgare & $8.29 \pm 0.5$ \\
Matricaria pubescens & $\mathbf{8 6 . 9 0} \pm 0.004$ \\
Ononis angustissima & $19.25 \pm 0.03$ \\
Oudneya africana & \\
(i) The pods & $\mathbf{1 0 0} \pm 0.004$ \\
(ii) The leaves & $51.38 \pm 0.02$ \\
Rhamnus alaternus & $43.18 \pm 0.08$ \\
Rhanterium adpressum & $76.75 \pm 0.003$ \\
Salvia officinalis & $\mathbf{7 7 . 8 1} \pm 0.004$ \\
Teucrium polium & $51.47 \pm 0.003$ \\
Thapsia garganica & $\mathbf{7 6 . 7 5} \pm 0.01$ \\
Trigonella foenum & $0 \pm 0.00$ \\
Zygophyllum album & $0 \pm 0.00$ \\
\hline
\end{tabular}

methanolic extracts $(88-258 \mu \mathrm{g} / \mathrm{mL})$. The $K_{i}$ value $(74-$ $393 \mu \mathrm{g} / \mathrm{mL}$ and $24-587 \mu \mathrm{g} / \mathrm{mL}$ for aqueous and methanolic extracts, resp.) was obtained from a Lineweaver-Burk and Dixon plots (Figures 1, 2, 3, and 4).

The $K_{i}$ value $(24-587 \mu \mathrm{g} / \mathrm{mL})$ was obtained from Lineweaver-Burk plots (Figures 1, 2, 3, and 4) which showed that the inhibition by all the investigated plants was noncompetitive mixed, competitive, and competitive mixed with low $K_{i}$ values of the order of $\mu \mathrm{g} / \mathrm{mL}$. The results are summarized in Table 5. These two types of inhibition can be explained. The competitive inhibition found can be explained by the fact that methanolic and aqueous extracts possess compounds with similar functional groups to those of the substrate starch, which has moved from the active site of the enzyme.

$K_{i}$ values with respect to concentrations of crude extracts determined representation of both Dixon and LineweaverBurk ranges from $74 \mu \mathrm{g} / \mathrm{mL}$ to $393 \mu \mathrm{g} / \mathrm{mL}$ and from $24 \mu \mathrm{g} / \mathrm{mL}$ to $587 \mu \mathrm{g} / \mathrm{mL}$ for the aqueous and methanolic extracts, respectively. It is also noted that it is "Salvia officinalis" which present a low $K_{i}$ for both aqueous and methanolic extracts which proves that this is a good inhibitor.

The best inhibitors were in the methanolic extracts for the six plants. The best value was recorded for the methanolic fraction of Salvia officinalis with a $K_{i}$ value of $24 \mu \mathrm{g} / \mathrm{mL}$ and methanolic fraction of Thapsia garganica was least potent with a $K_{i}$ value of $587 \mu \mathrm{g} / \mathrm{mL}$. The higher activity of the methanolic extracts as compared to the aqueous extract can be attributed to the presence of higher amounts of polyphenols as compared to aqueous extracts. It means that they are more efficient in cell walls and seeds degradation which have unpolar character and cause polyphenols to be released from cells. More useful explanation for the decrease in activity of aqueous extract can be ascribed to the enzyme polyphenol oxidase, which degrades polyphenols in water extracts, whereas in methanol and ethanol they are inactive. Moreover, water is a better medium for the occurrence of the microorganisms [34].

In conclusion, we can say that no standard extraction procedure can lead to the degradation of phytochemicals present in plants and variations leading to the lack of reproducibility. But efforts should be made to produce processes as consistent as possible in quality (in the narrowest possible range) and to develop and follow the best extraction methods.

All the plants showed different values of inhibition constants with the majority being close to each other and all above $20 \mu \mathrm{g} / \mathrm{mL}$. This can be explained by the fact that the two solvents used for the extraction distilled water and methanol may have the same polar molecules with near chemical structure and were able to react similarly against the enzymes and, as the inhibition phenomenon is the result of a synergy between several molecules, these values could be lower if the molecules responsible for inhibition in the two solvents of extraction were together in the same reaction medium.

If we compare the values of $K_{i}$ in this work with those of the study of Khacheba et al. [33], we found that our values are higher. This made can conclude that our samples are low inhibteur which is the result of the type of extraction; our extracts are too polar and have extracte all polar compounds may interfere with the mechanism of inhibition or by the fact that the plants studied by Khacheba and their collaborator present the exsitance of compounds with different structure gives them a largest inhibitory activity. By comparison with another study of Shobana et al. [8] whose values range from 2 to $10 \mu \mathrm{g}$, our values are still insignificant.

The general techniques of medicinal plant extraction include maceration, infusion, percolation, digestion, decoction, hot continuous extraction (Soxhlet), aqueousalcoholic extraction by fermentation, countercurrent extraction, microwave-assisted extraction, ultrasound extraction (sonication), supercritical fluid extraction, and phytonic extraction (with hydrofluorocarbon solvents). However the quality of the extract of these techniques is influenced by several parameters, which are plant part used as starting material, solvent used for extraction, and extraction procedure [34]. We conclude that the plant source (the nature of the plant material, its origin, growth stage, climatic conditions for growth, degree of processing, moisture content, and particle size) [34] remains the first point influencing the synthesis of inhibitory molecules and their action which are influenced by the atmospheric and climatic conditions under which the plant is grown. The phenolic compounds and other secondary metabolites (responsible for the pharmacological effects of the plant) represent a chemical interface between the plants and the environment, and their synthesis is often affected by environmental factors [35]. 


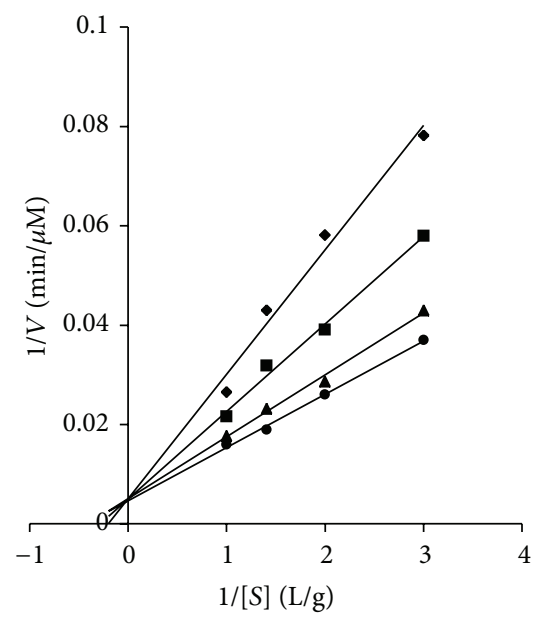

(a)

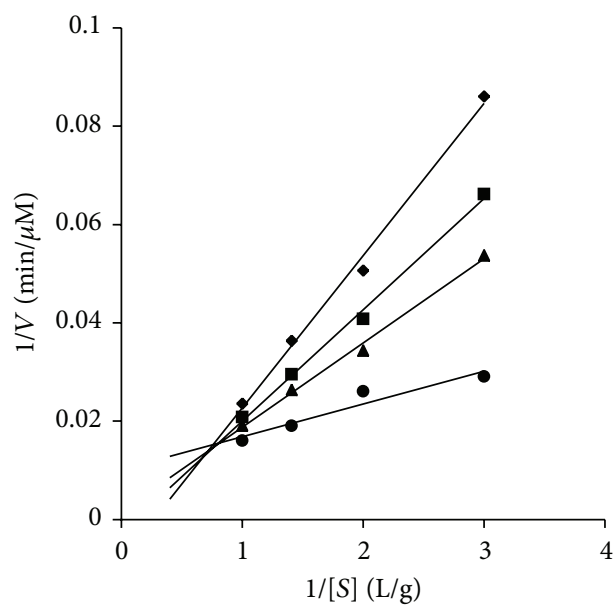

(c)

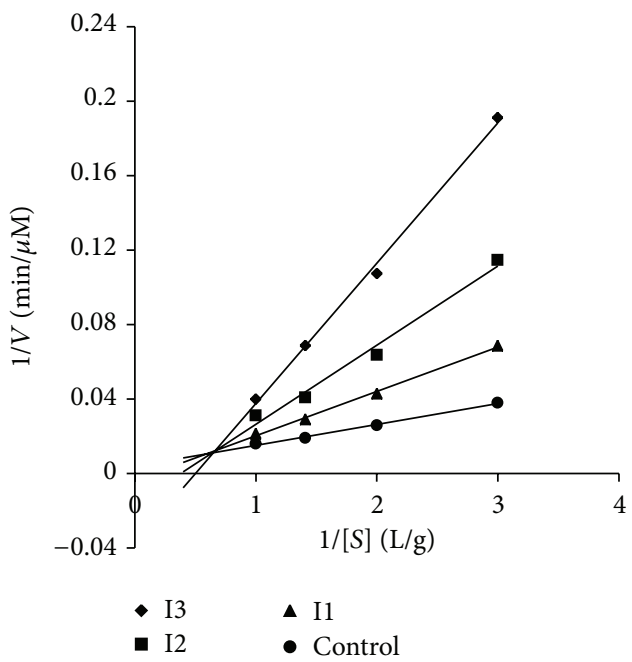

(e)

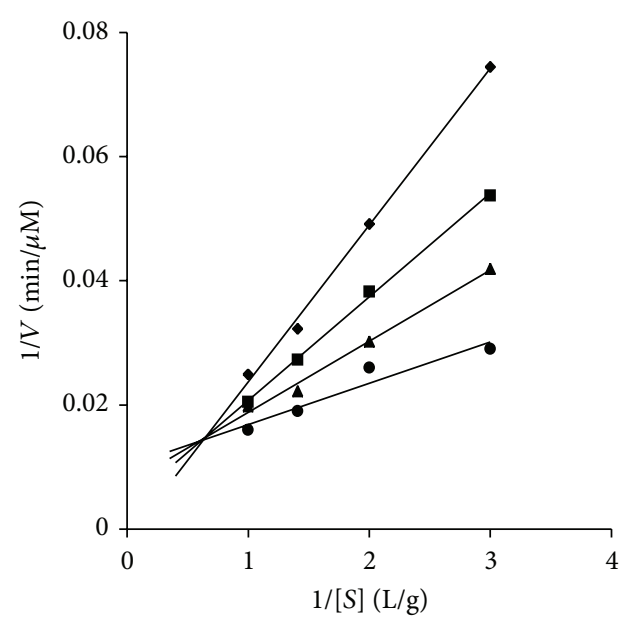

(b)

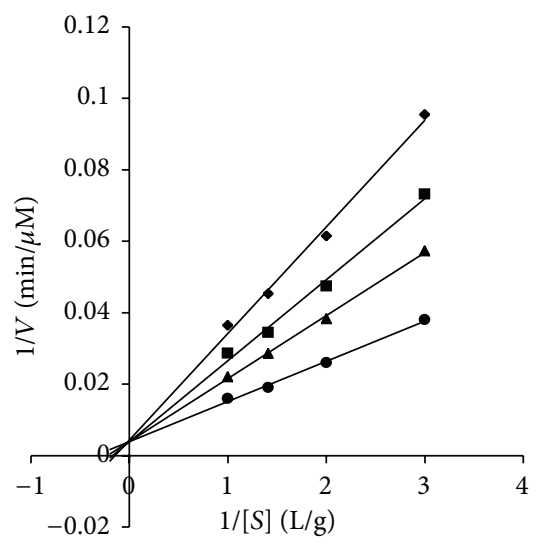

(d)

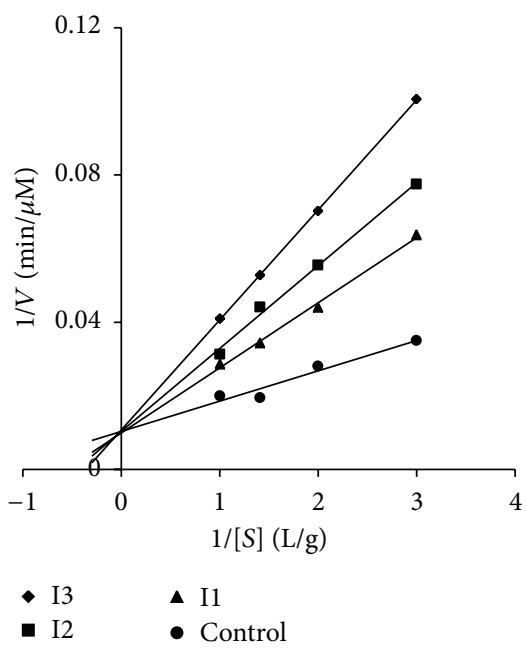

(f)

Figure 1: Lineweaver-Burk plots of inhibition of $\alpha$-amylase according to the total phenol concentration of the aqueous fraction plant of (a) Cistus; (b) Equisetum arvense (the grains); (c) Matricaria pubescens; (d) Oudneya africana (the pods); (e) Salvia officinalis; (f) Thapsia garganica. Activity was determined by formation of maltose at several substrate concentrations ranging from 0.2 to $0.6 \mathrm{~g} / \mathrm{L}$ and three concentrations of inhibitors I1, I2, and I3 ranging from 88 to $258 \mu \mathrm{g} / \mathrm{mL}$. 


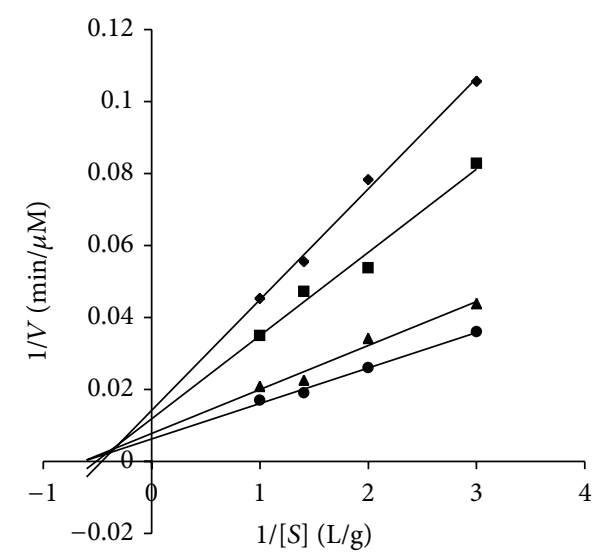

(a)

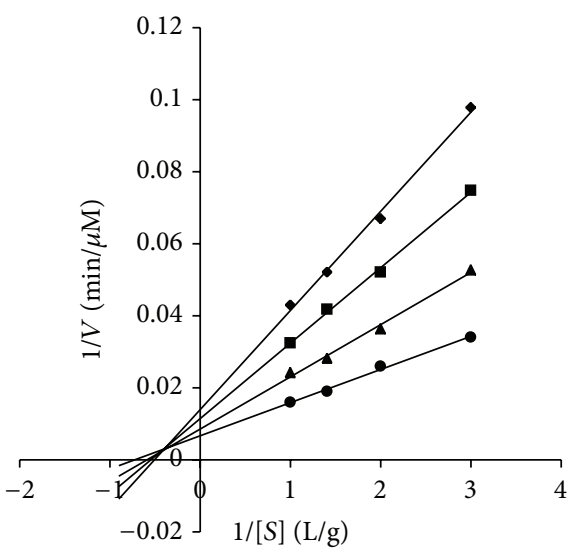

(c)

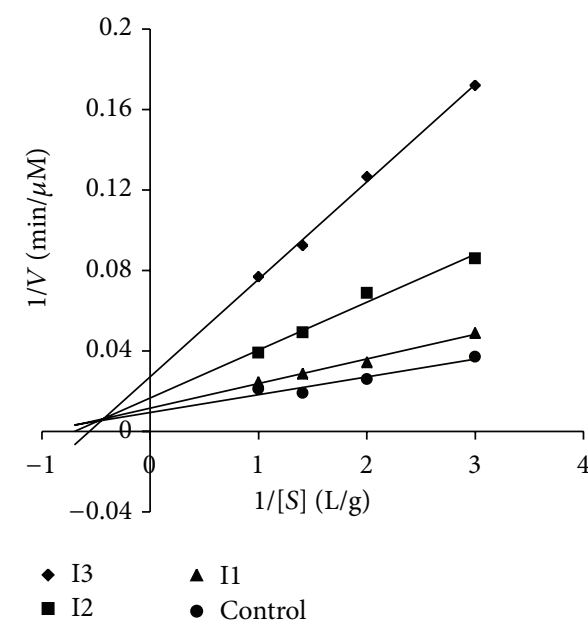

(e)

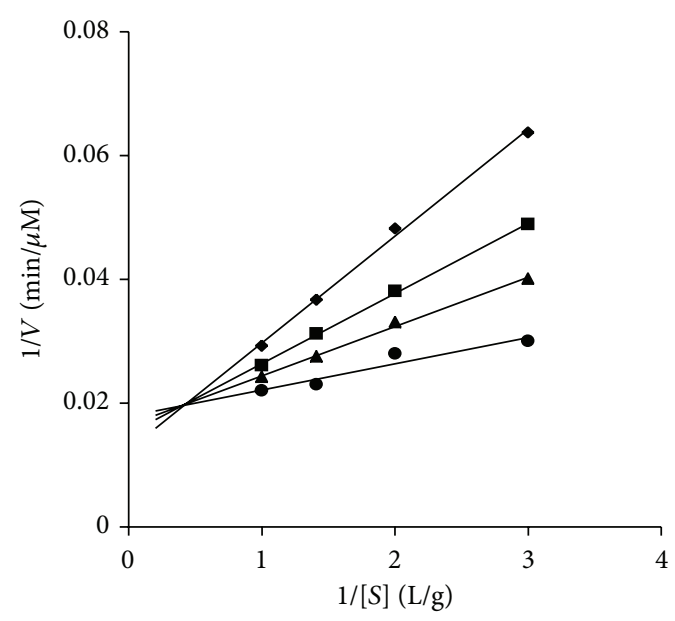

(b)

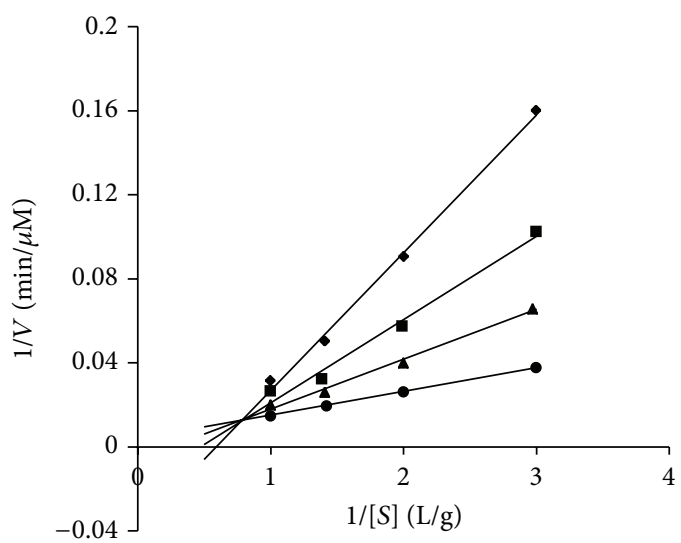

(d)

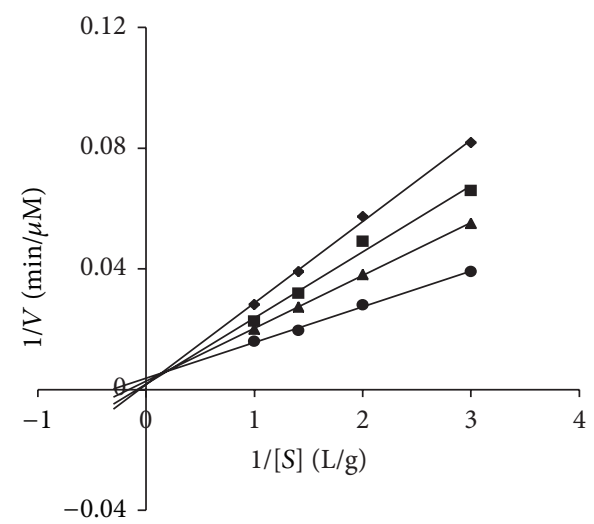

$\begin{array}{ll}-\mathrm{I} 3 & \Delta \mathrm{I} 1 \\ \text { - } \mathrm{I} 2 & - \text { Control }\end{array}$

(f)

FIGURE 2: Lineweaver-Burk plots of inhibition of $\alpha$-amylase according to the total phenol concentration of the methanolic fraction plant of (a) Cistus; (b) Equisetum arvense (the grains); (c) Matricaria pubescens; (d) Oudneya africana (the pods); (e) Salvia officinalis; (f) Thapsia garganica. Activity was determined by formation of maltose at several substrate concentrations ranging from 0.2 to $0.6 \mathrm{~g} / \mathrm{L}$ and three concentrations of inhibitors I1, I2, and I3 ranging from 88 to $258 \mu \mathrm{g} / \mathrm{mL}$. 


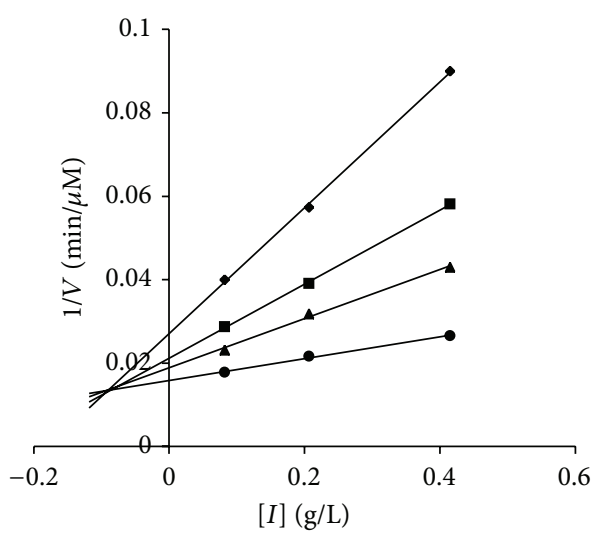

(a)

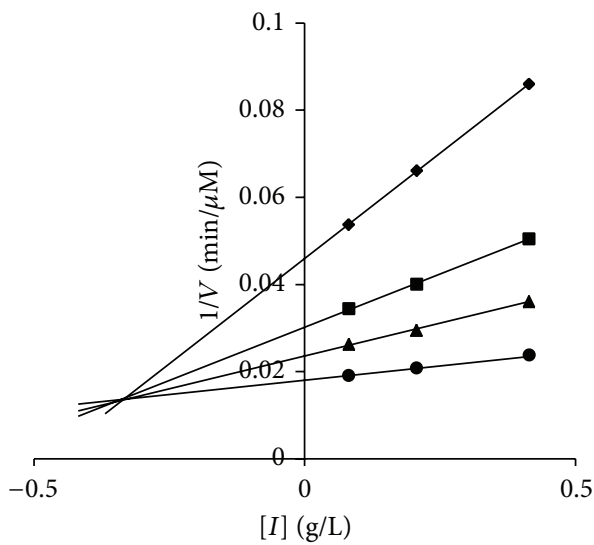

(c)

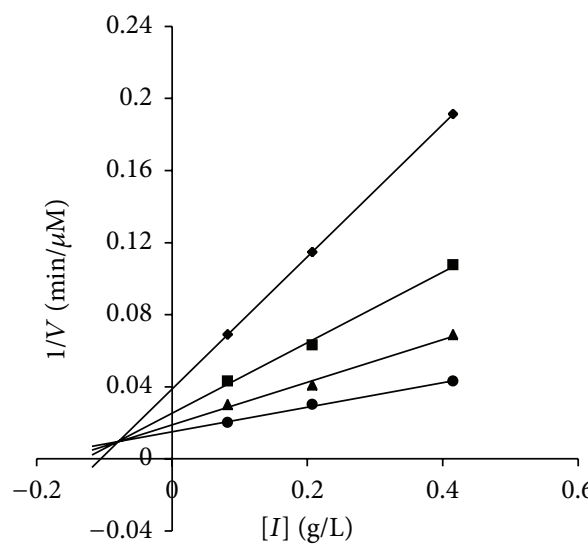

- $\mathrm{S} 1 \quad$ a $\mathrm{S} 3$

- $\mathrm{S} 2 \quad \mathrm{~S} 4$

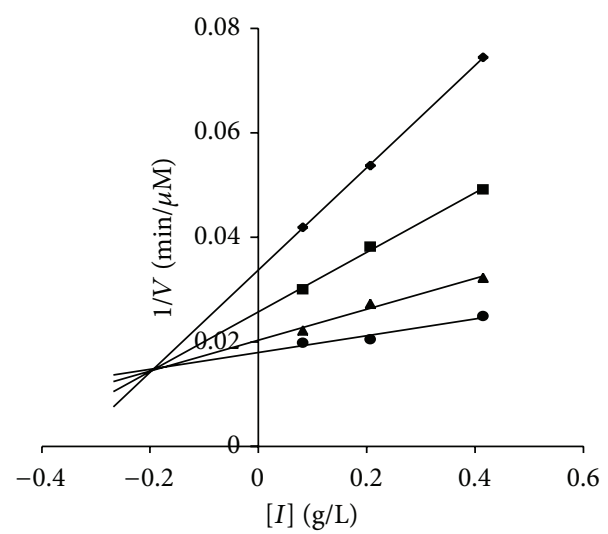

(b)

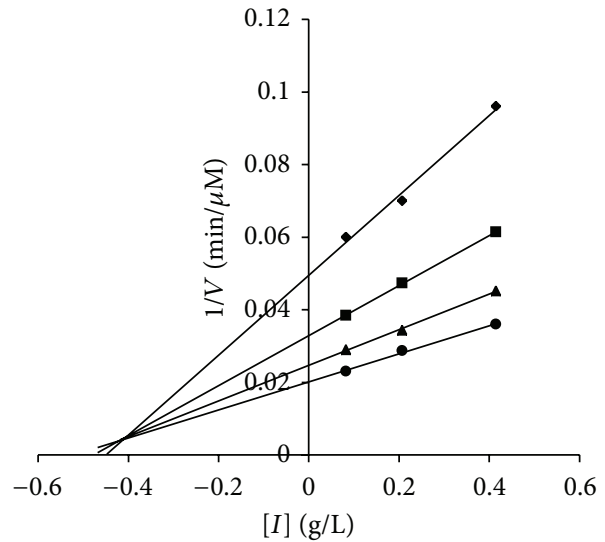

(d)

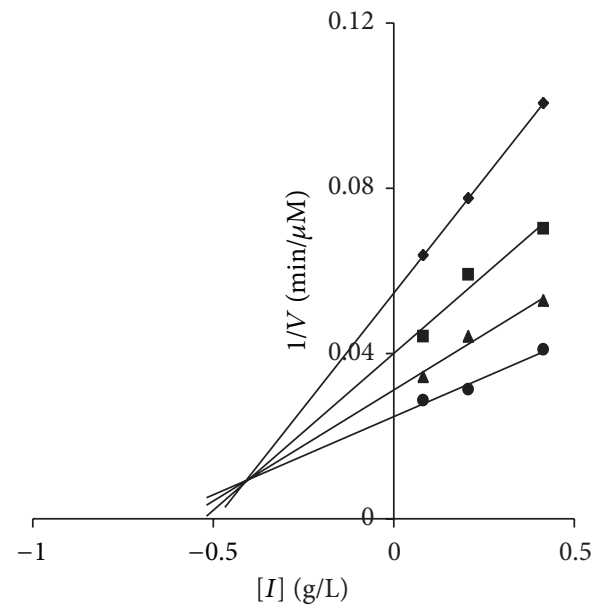

- $\mathrm{S} 1 \quad \Delta \mathrm{S} 3$

- S2 $\mathrm{S} 4$

(e)

(f)

FIGURE 3: Dixon plots of inhibition of $\alpha$-amylase according to the total phenol concentration of the aqueous fraction plant of (a) Cistus; (b) Equisetum arvense (the grains); (c) Matricaria pubescens; (d) Oudneya africana (the pods); (e) Salvia officinalis; (f) Thapsia garganica. Activity was determined by formation of maltose at several substrate concentrations ranging from 0.2 to $0.6 \mathrm{~g} / \mathrm{L}$. 


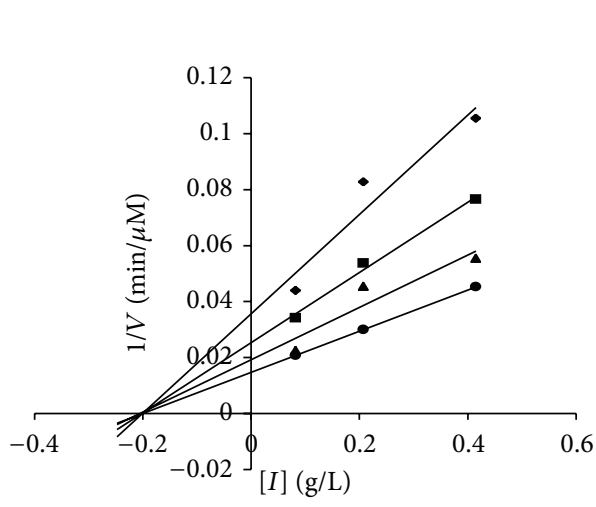

(a)

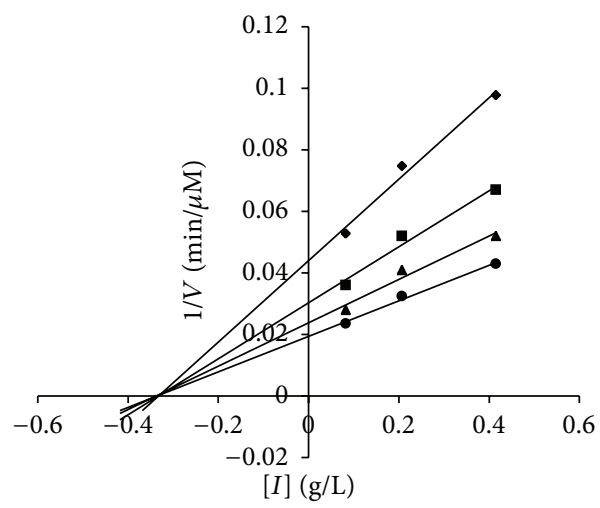

(c)

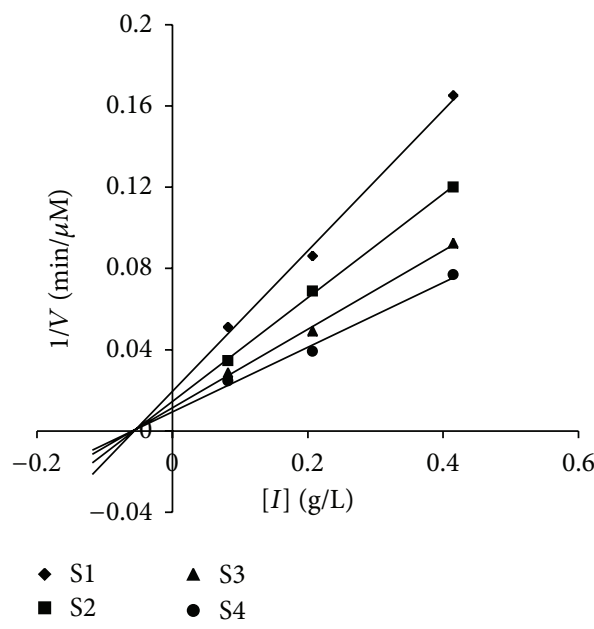

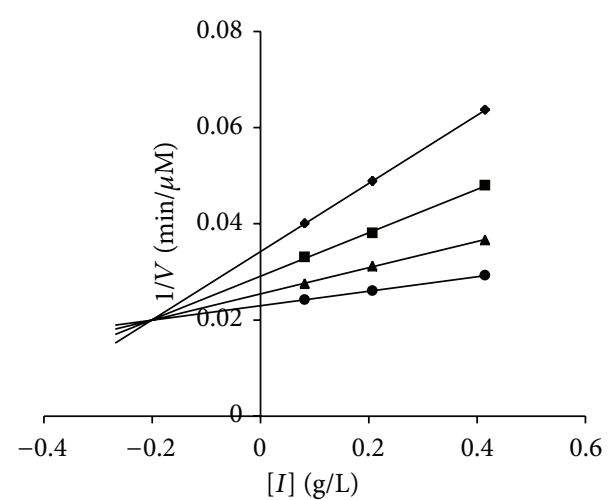

(b)

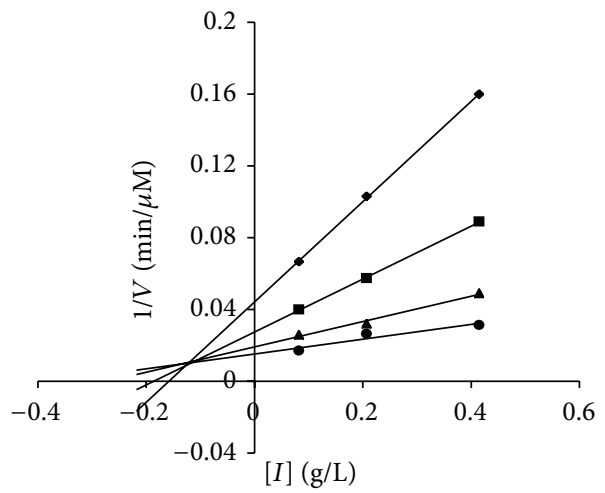

(d)

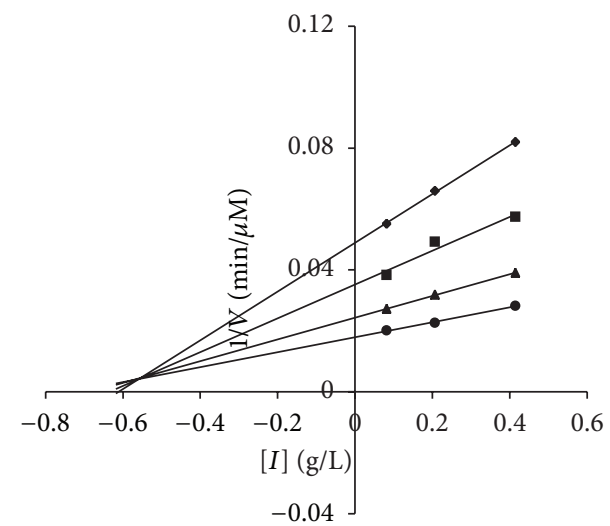

$\begin{array}{rll}\mathrm{S} 1 & \mathrm{~S} 3\end{array}$

- S2 $\quad$ S 54

FIGURE 4: Dixon plots of inhibition of $\alpha$-amylase according to the total phenol concentration of the methanolic fraction plant of (a) Cistus; (b) Equisetum arvense (the grains); (c) Matricaria pubescens; (d) Oudneya africana (the pods); (e) Salvia officinalis; (f) Thapsia garganica. Activity was determined by formation of maltose at several substrate concentrations ranging from 0.2 to $0.6 \mathrm{~g} / \mathrm{L}$.

Secondly, the successful determination of biologically active compounds from plant material is largely dependent on the type of solvent used in the extraction procedure. The factors affecting the choice of solvent are quantity of phytochemicals to be extracted, rate of extraction, diversity of different compounds extracted, diversity of inhibitory compounds extracted, ease of subsequent handling of the extracts, toxicity of the solvent in the bioassay process, and potential health hazard of the extractants [34].

And finally the type of extraction variations in different extraction methods that will affect quantity and secondary metabolite composition of an extract depends upon type of 
TABLE 5: $K_{i}$ and inhibitor type for total aqueous and methanolic extracts obtained for $\alpha$-amylase.

\begin{tabular}{lcc}
\hline Name of plant & Type of inhibition & $K_{i}(\mu \mathrm{g} / \mathrm{mL})$ \\
\hline Cistus & Aqueous extracts & $240 \pm 0.004$ \\
Equisetum arvense (Les grains) & Inhibition competitive & $210 \pm 0.001$ \\
Matricaria pubescens & Inhibition competitive mixed & $350 \pm 0.005$ \\
Oudneya africana (the pods) & Inhibition competitive mixed & $370 \pm 0.007$ \\
Salvia officinalis & Inhibition competitive & $74 \pm 0.004$ \\
Thapsia garganica & Inhibition competitive mixed \\
& Inhibition competitive & $393 \pm 0003$ \\
Cistus & Methanolic extracts & $220 \pm 0.002$ \\
Equisetum arvense (the grains) & Inhibition noncompetitive mixed \\
Matricaria pubescens & Inhibition competitive mixed & $210 \pm 0.001$ \\
Oudneya africana (the pods) & Inhibition noncompetitive mixed & $360 \pm 0.006$ \\
Salvia officinalis & Inhibition competitive mixed & $130 \pm 0.003$ \\
Thapsia garganica & Inhibition noncompetitive mixed & $24 \pm 0.004$ \\
& Inhibition competitive mixed & $587 \pm 0.007$ \\
\hline
\end{tabular}

extraction, time of extraction, temperature, nature of solvent, solvent concentration, and polarity [34]. The length of the extraction period must be also taken into consideration, which depends on solvent used, $\mathrm{pH}$ of the solvent, temperature, particle size of the plant tissues, and the solvent-tosample ratio [34].

It may be thought that the inhibitory potency of the plant extracts is not limited to the phenolic content but may be due to the presence of some individual active phenolic compounds.

Thus the inhibitory potency of an extract can not just be explained on the basis of its phenolic content but also requires its proper characterization. There are several reasons to explain the ambiguous relationship between inhibitory potency and total phenolics: total phenolics content did not include all the possible inhibitors; the synergism among the inhibitors in the mixture accounted for the inhibition; however, it was dependent not only on the concentration of individual inhibitors, but on the structure and interaction among them as well.

\section{Conclusion}

The relative inefficacy of alpha-amylase inhibitors in affecting human digestion of starch has been highlighted by recent scientific and public controversy over the commercial sales of so-called starch-blockers or slimming pills [36]. Alphaamylase and its inhibitors are drug-design targets for the development of compounds for treatment of diabetes, obesity, and hyperlipidaemia [37].

Plant extracts have long been used for the ethnomedical treatment of diabetes in various systems of medicine and are currently accepted as an alternative for diabetic therapy. Inhibitory activity against amylase by flavonoids and anthocyanins has been reported $[38,39]$. Herbs used in traditional Algerian medicine for diabetes mellitus treatments are known to contain phenolic compounds, as well as the flavonoids. We hypothesize that the health benefits of these herbs against diabetes mellitus may be due to the amylase-inhibiting activity of the phenolic compounds.

In the current study, we investigated the effect of aqueous and methanolic extracts from some Algerian medicinal plants on fungal $\alpha$-amylase.

We have demonstrated, for the first time in vitro, the inhibitory effect of some Algerian plant extracts on the $\alpha$ amylase. The results obtained through this test show that the majority of these plants have significant inhibitory effects. The values of the constants $\left(K_{i}\right)$ thus obtained indicate that these plants can be investigated in pharmacotherapeutic for eventual treatment, including the plant "Salvia officinalis" which presented the lowest values of inhibition constant for both aqueous and methanolic extracts.

The phenolic compounds present in these plants may also serve as lead compounds for the synthesis of a series of inhibitors. In several cases, the use of the plants and their respective therapeutic prescription in popular medicine are not easy to understand, and we can question if there is a relation between the therapeutic properties of these plants and their inhibitory effects on $\alpha$-amylase.

Our study is the first report on potential inhibition of these plants extracts of digestive enzyme $\alpha$-amylase. In conclusion, the results from this study give scientific support to the use of these plants in traditional medicine for the treatment of diabetes. This study would be helpful to explain the pharmacological mechanism and also to develop medicinal preparations and nutraceutical or functional foods for diabetes and related symptoms.

Further isolation of the bioactive compounds responsible for the inhibition of the enzyme must be done to elucidate their molecular structure and to study their mechanism of action to confirm their antidiabetic activity. In addition, more experiments must be carried out in vivo to pave the way to the development of new agents for the treatment of diabetes and its complications.

It is possible to expand the panel inhibition tests, using other substrates or other types of enzymes. There are still 
other useful local plants that were not analyzed and that should determine their potential in the study area.

This work provided a new ethnopharmacological and phytochemicals knowledge about local plants in the region of Laghouat, and helped to highlight the role of natural compounds in the regulation of oxidative stress and normalization of blood sugar disorders.

\section{Conflict of Interests}

The authors declare that there is no conflict of interests regarding the publication of this paper.

\section{References}

[1] J. Feng, X. W. Yang, and T. H. Liu, "Bio-assay guided isolation and identification of $\alpha$-glucosidase inhibitors from the leaves of Aquilaria sinensis," Phytochemistry, vol. 72, no. 2-3, pp. 242-247, 2011.

[2] A. Gholamhoseinian, H. Fallah, F. Sharifi-Far, and M. Mirtajaddini, "The inhibitory effect of some Iranian plants extracts on the alpha glucosidase," Iranian Journal of Basic Medical Sciences, vol. 11, pp. 1-9, 2008.

[3] B. Nickavar and G. Mosazadeh, "Influence of three morus species extracts on $\alpha$-amylase activity," Iranian Journal of Pharmaceutical Research, vol. 8, no. 2, pp. 115-119, 2009.

[4] S. Sancheti and S. Seo, "Chaenomeles sinensis: a potent $\alpha$-and $\beta$-glucosidase inhibitor," The American Journal of Pharmacology and Toxicology, vol. 4, no. 1, pp. 8-11, 2009.

[5] M. S. Deutschländer, M. van de Venter, S. Roux, J. Louw, and N. Lall, "Hypoglycaemic activity of four plant extracts traditionally used in South Africa for diabetes," Journal of Ethnopharmacology, vol. 124, no. 3, pp. 619-624, 2009.

[6] B. Nickavar, A. Alinaghi, and M. Kamalinejad, "Evaluation of the antioxidant properties of five Mentha species," Iranian Journal of Pharmaceutical Research, vol. 7, no. 3, pp. 203-209, 2008.

[7] M. R. Bhandari, N. Jong-Anurakkun, G. Hong, and J. Kawabata, " $\alpha$-Glucosidase and $\alpha$-amylase inhibitory activities of Nepalese medicinal herb Pakhanbhed (Bergenia ciliata, Haw.)," Journal of Food Chemistry, vol. 106, no. 1, pp. 247-252, 2008.

[8] S. Shobana, Y. N. Sreerama, and N. G. Malleshi, "Composition and enzyme inhibitory properties of finger millet (Eleusine coracana L.) seed coat phenolics: mode of inhibition of $\alpha$ glucosidase and pancreatic amylase," Food Chemistry, vol. 115, no. 4, pp. 1268-1273, 2009.

[9] B. Nickavar and G. Mosazadeh, "Influence of three morus species extracts on $\alpha$-amylase activity," Iranian Journal of Pharmaceutical Research, vol. 8, no. 2, pp. 115-119, 2009.

[10] S. Heo, J. Hwang, J. Choi, J. Han, H. Kim, and Y. Jeon, "Diphlorethohydroxycarmalol isolated from Ishige okamurae, a brown algae, a potent $\alpha$-glucosidase and $\alpha$-amylase inhibitor, alleviates postprandial hyperglycemia in diabetic mice," European Journal of Pharmacology, vol. 615, no. 1-3, pp. 252-256, 2009.

[11] H. Ali, P. J. Houghton, and A. Soumyanath, " $\alpha$-Amylase inhibitory activity of some Malaysian plants used to treat diabetes; with particular reference to Phyllanthus amarus," Journal of Ethnopharmacology, vol. 107, no. 3, pp. 449-455, 2006.

[12] A. Fred-Jaiyesimi, A. Kio, and W. Richard, " $\alpha$-Amylase inhibitory effect of $3 \beta$-olean-12-en-3-yl (9Z)-hexadec-9-enoate isolated from Spondias mombin leaf," Food Chemistry, vol. 116, no. 1, pp. 285-288, 2009.

[13] H. Gao, Y.-N. Huang, B. Gao, P. Li, C. Inagaki, and J. Kawabata, "Inhibitory effect on $\alpha$-glucosidase by Adhatoda vasica Nees," Journal of Food Chemistry, vol. 108, no. 3, pp. 965-972, 2008.

[14] V. Le Berre-Anton, C. Bompard-Gilles, F. Payan, and P. Rougé, "Characterization and functional properties of the $\alpha$-amylase inhibitor ( $\alpha-\mathrm{AI})$ from kidney bean (Phaseolus vulgaris) seeds," Biochimica et Biophysica Acta, vol. 1343, no. 1, pp. 31-40, 1997.

[15] R. H. Nagaraj and T. N. Pattabiraman, "Purification and properties of an $\alpha$-amylase inhibitor specific for human pancreatic amylase from proso (Panicium miliaceum) seeds," Journal of Biosciences, vol. 7, no. 3-4, pp. 257-268, 1985.

[16] M. Santimone, R. Koukiekolo, Y. Moreau et al., "Porcine pancreatic $\alpha$-amylase inhibition by the kidney bean (Phaseolus vulgaris) inhibitor ( $\alpha$-AIl) and structural changes in the $\alpha$ amylase inhibitor complex," Biochimica et Biophysica Acta, vol. 1696, no. 2, pp. 181-190, 2004.

[17] S. Chethan, Y. N. Sreerama, and N. G. Malleshi, "Mode of inhibition of finger millet malt amylases by the millet phenolics," Food Chemistry, vol. 111, no. 1, pp. 187-191, 2008.

[18] C. M. Ma, N. Sato, X. Y. Li, N. Nakamura, and M. Hattori, "Flavan-3-ol contents, anti-oxidative and $\alpha$-glucosidase inhibitory activities of Cynomorium songaricum," Food Chemistry, vol. 118, no. 1, pp. 116-119, 2010.

[19] J. Médart, Manuel pratique de nutrition: Lálimentation préventive et curative, édition de Boecks, 2009.

[20] S. Sancheti, S. Sancheti, and S.-Y. Seo, "Chaenomeles sinensis: A potent $\alpha$-and $\beta$-glucosidase inhibitor," The American Journal of Pharmacology and Toxicology, vol. 4, no. 1, pp. 8-11, 2009.

[21] N. Kambouche, B. Merah, A. Derdour et al., "Hypoglycemic and antihyperglycemic effects of Anabasis articulata (Forssk) Moq (Chenopodiaceae), an Algerian medicinal plant," African Journal of Biotechnology, vol. 8, no. 20, pp. 5589-5594, 2009.

[22] B. I. Giner-Chavez, Condensed tannins in tropical forages [Ph.D. thesis], Cornell University, Ithaca, NY, USA, 1996.

[23] T. Bahorun, "Substances naturelles actives: la flore mauricienne, une source dapprovisionnement potentielle," in Proceedings of the 2nd Annual Meeting of Agricultural Scientists, J. A. Lalouette, D. Y. Bachraz, N. Sukurdeep, and B. D. Seebaluck, Eds., pp. 8394, Food and Agricultural Research Council, 1998.

[24] S. Dygert, L. H. Li, D. Florida, and J. A. Thoma, "Determination of reducing sugar with improved precision," Analytical Biochemistry, vol. 13, no. 3, pp. 367-374, 1965.

[25] M. Naczk and F. Shahidi, "Extraction and analysis of phenolics in food," Journal of Chromatography A, vol. 1054, no. 1-2, pp. 95111, 2004.

[26] A. Andrade-Cetto, J. Becerra- Jiménez, and R. CàrdenasVàzquez, "Alpha-glucosidase-inhibiting activity of some Mexican plants used in the treatment of type II diabetes," Ethnopharmacology, vol. 116, pp. 27-32, 2007.

[27] S. P. Kalidas and P. McCue, "Inhibitory effects of rosmarinic acid extracts on porcine pancreatic amylase in vitro," Asia Pacific Journal of Clinical Nutrition, vol. 13, no. 1, pp. 101-106, 2004.

[28] E. Apostolidis, Y. I. Kwon, and K. Shetty, "Inhibitory potential of herb, fruit, and fungal-enriched cheese against key enzymes linked to type 2 diabetes and hypertension," Innovative Food Science and Emerging Technologies, vol. 8, no. 1, pp. 46-54, 2007.

[29] S. S. Ali, N. Kasoju, A. Luthra et al., "Indian medicinal herbs as sources of antioxidants," Food Research International, vol. 41, no. 1, pp. 1-15, 2008. 
[30] X. Han, T. Shen, and H. Lou, "Dietary polyphenols and their biological significance," International Journal of Molecular Sciences, vol. 8, no. 9, pp. 950-988, 2007.

[31] A. Djeridane, M. Yousfi, J. M. Brunel, N. Vidal, E. H. Ajandouz, and P. Stocker, "Inhibition of porcine liver carboxylesterase by a new flavone glucoside isolated from Deverra scoparia," Chemico-Biological Interactions, vol. 172, no. 1, pp. 22-26, 2008.

[32] A. Djeridane, M. Yousfi, B. Nadjemi, S. Maamri, F. Djireb, and P. Stocker, "Phenolic extracts from various Algerian plants as strong inhibitors of porcine liver carboxylesterase," Journal of Enzyme Inhibition and Medicinal Chemistry, vol. 21, no. 6, pp. 719-726, 2006.

[33] I. Khacheba, A. Djeridane, A. Kameli, and M. Yousfi, "he inhibitory effect of some algerian plants phenolics extracts on the $\alpha$-glucosidase and $\alpha$-amylase activities and their antioxidant activity," Current Enzyme Inhibition, vol. 10, pp. 59-68, 2014.

[34] P. Tiwari, B. Kumar, M. Kaur, G. Kaur, and H. Kaur, "Phytochemical screening and extraction: a review," Internationale Pharmaceutica Sciencia, vol. 1, no. 1, pp. 98-106, 2011.

[35] B. L. Sampaio, M. T. F. Bara, P. H. Ferri, S. da Costa Santos, and J. R. de Paula, "Influence of environmental factors on the concentration of phenolic compounds in leaves of Lafoensia pacari," Brazilian Journal of Pharmacognosy, vol. 21, no. 6, pp. 1127-1137, 2011.

[36] M. Richardson, Methods in Biochemistry, vol. 5, Academic Press, 1991.

[37] L. Octivio and D. Rigden, "Activity of wheat $\alpha$-amylase inhibitors towards bruchid $\alpha$-amylases and structural explanation of observed specificities," European Journal of Biochemistry, vol. 267, pp. 2166-2173, 2000.

[38] J. Kim, C. Kwon, and K. H. Son, "Inhibition of Alphaglucosidase and Amylase by Luteolin, a Flavonoid," Bioscience, Biotechnology and Biochemistry, vol. 64, no. 11, pp. 2458-2461, 2000.

[39] T. Matsui, T. Ueda, T. Oki, K. Sugita, N. Terahara, and K. J. Matsumoto, "Alpha-glucosidas inhibition isolated anthocyanins," Journal of Agricultural and Food Chemistry, vol. 49, pp. 19481951, 2001. 

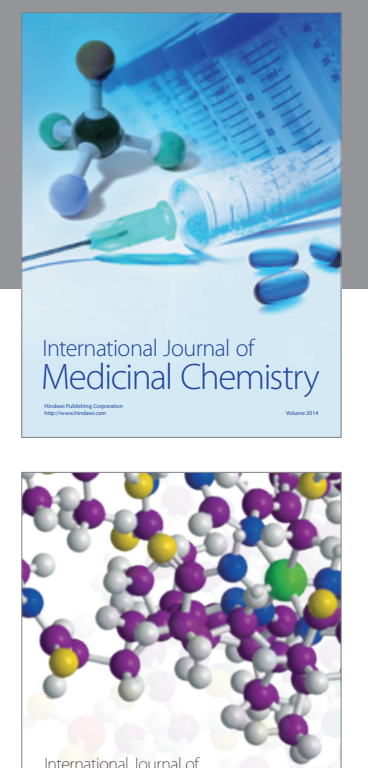

\section{Carbohydrate} Chemistry

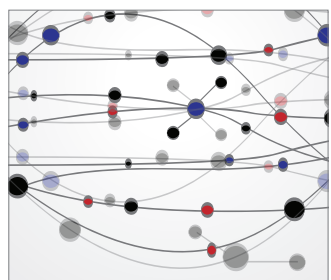

The Scientific World Journal
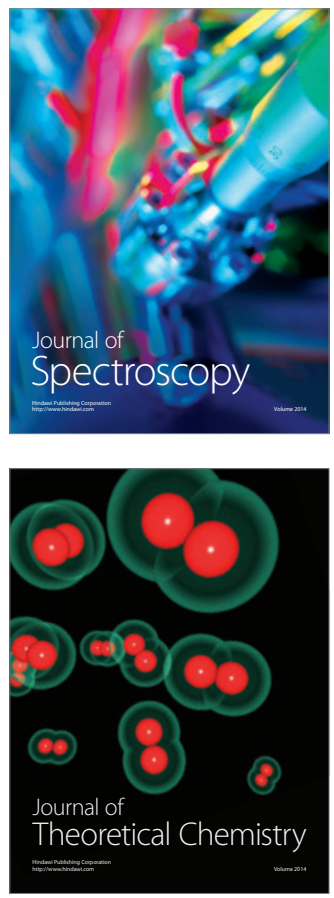
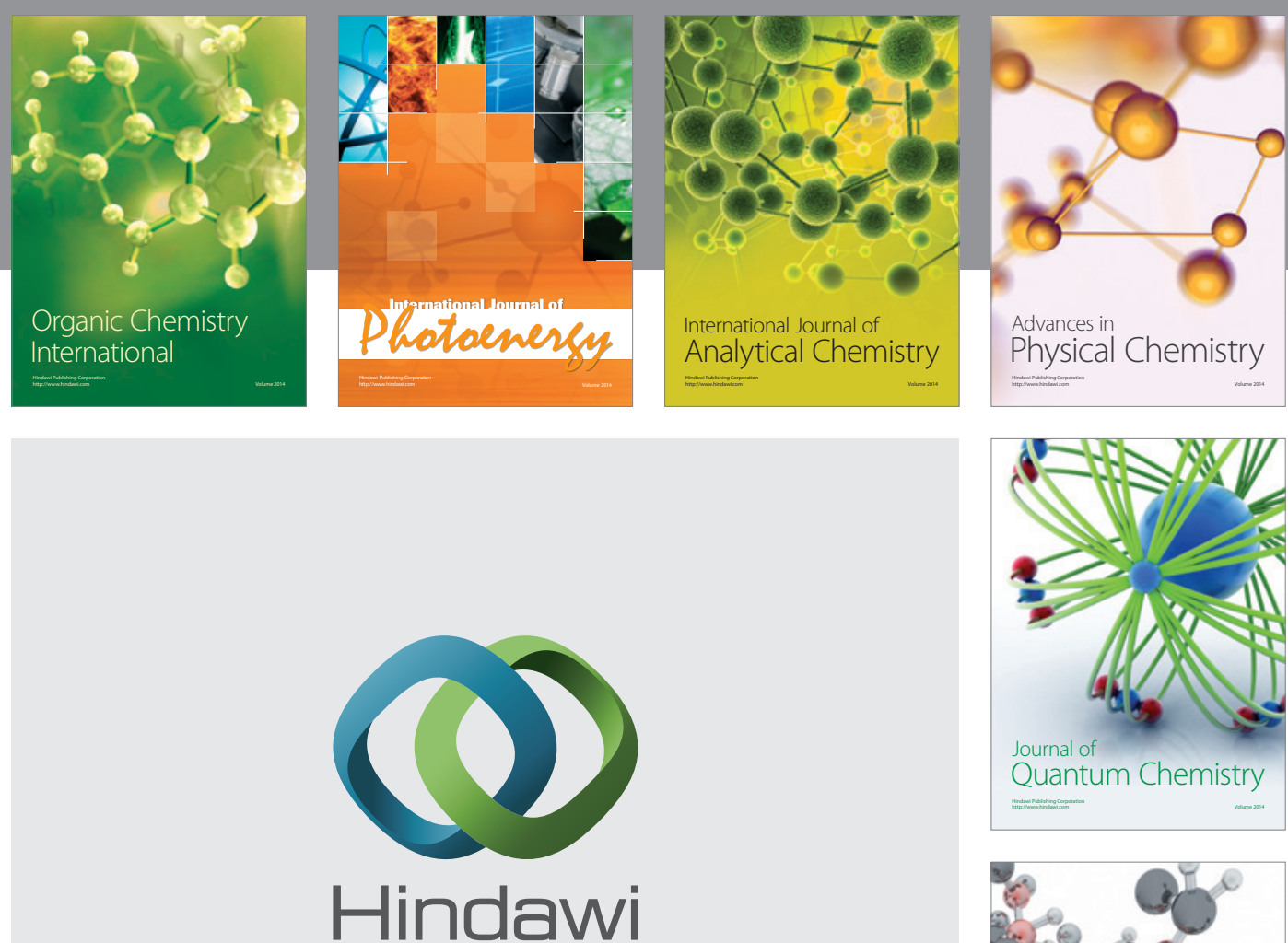

Submit your manuscripts at

http://www.hindawi.com

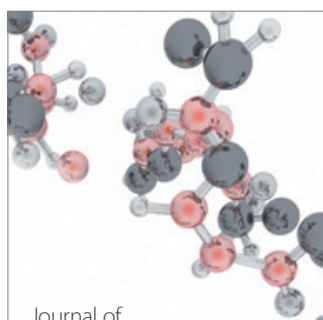

Analytical Methods

in Chemistry

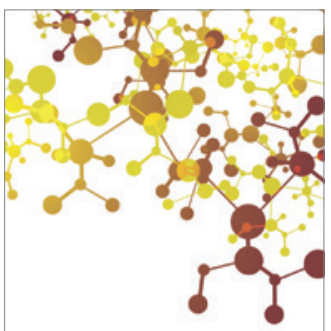

Journal of

Applied Chemistry

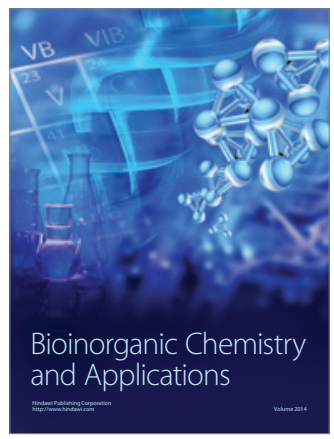

Inorganic Chemistry
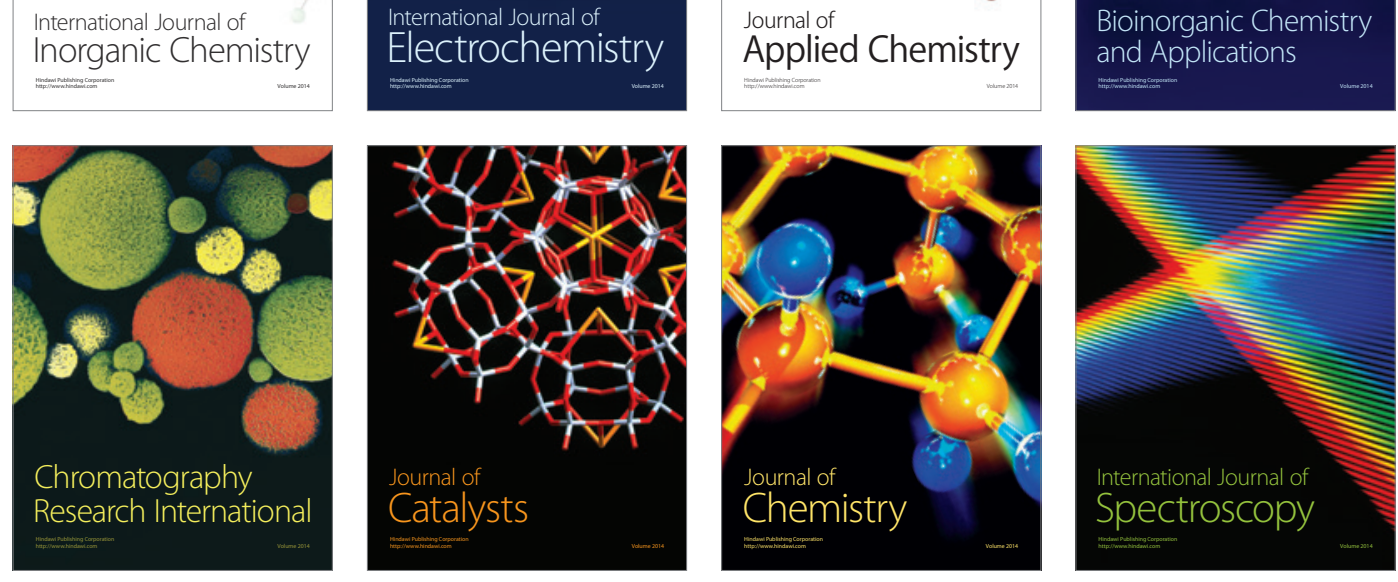